\title{
Integrated Analysis of the linkage between the Strategic Alignment Maturity Level and the Information and Communication Technology Evaluation Management
}

\author{
Rodolfo Alberto Pérez Estrada ${ }^{1}$, Liliana Angélica Guerrero Ramos ${ }^{2}$, \\ José Leonel García Sánchez ${ }^{3}$, Rafael Palacios Torres ${ }^{4}$ \\ ${ }^{1}$ Petróleos Mexicanos. ${ }^{2}$ Universidad Autónoma de Coahuila. \\ ${ }^{3}$ Universidad Autónoma del Carmen ${ }^{4}$ University of Texas Panamerican. \\ rodolfo.alberto.perez@pemex.com, lilianaguerrero7@gmail.com, \{j1_garcias, rpalacios11\}@ hotmail.com,
}

\begin{abstract}
The integration between the Business and Information Technologies (IT) has become one of the main priorities in today's organizations. To face this issue, the results of this investigation have been centered in efforts to link a model to identify the level of maturity of the strategic integration of the IT with the variables proposed in the Administrative Manual of General Applications in Regards to the Subject of Information and Communications Technologies (MAAGTIC).
\end{abstract}

This study identifies the associated variables that make up the MAAGTIC Government management level with the criteria of the Luftman's Strategic Alignment Maturity Model, as a result of the multivariable techniques applied in the study.

Key Words: Strategic alignment, Maturity level, Correspondence analysis, Decision tree, Discriminant analysis.

\section{Introduction}

The strategic alignment of the Business with the IT's has been used by organizations to create and improve the efficiency, reduce costs, improve the consumer-provider relationship, and to create new products and Business solutions.

The Business-IT alignment symbolizes the degree in which the mission, objectives and plans of the IT's are backed up by the mission, objectives and plans of the Business department.

With the goal of aligning the IT with the Business process models, the need to homologize and to support them both arises, which is done by employing the best practices, exploring the ones currently being used by companies and adapting them to said companies, allowing the arrival of new elements beneficial to the support of Business processes, with the goal of establishing strategies that bring a competitive advantage by the means of IT tools that contribute to the alignment of objectives, offering key strategic elements such as executive support for decision making.

For Symons (1) the alignment between Business and IT services objectives is one of the key strategies that organizations need to implement in order to manage their businesses in a successful manner.

According to Burlton (2), "Strategic alignment is defined as the right entailment of the organization's priorities and the enterprise processes which allow a continuous and effective action in order to improve the organization's output".

Although the benefits of an IT and Business alignment have been previously proven, many studies (3-5) indicate that organizations continue to be unsuccessful at implementing the Business IT binomial. No matter what methodological frameworks and better practices and standards would so guarantee, it is still a priority that these are adopted, implemented, prioritized and planned in order to make effective use of them. (6)

Some of the main reasons behind the Literature analysis and low success rates on the Business and IT alignments is the lack of universal alignment definition, the search for an alignment strategy, and the absence of appropriate tools to measure the success of the alignment. $(3,7,8)$

By making use of better practices, models, reference frameworks and methodological standards, organizations are looking for IT Solutions that allows them to align their operations with their Business objectives, thus evaluating the impact of implementing new applications, both to the Business growth and to the organization long term plans versus IT services.

It is for that reason that the main objective behind this work is to relate the characteristics of a Model to identify 
the level of maturity of the IT's Strategical alignment with the variables proposed by the Administrative Manual of General Applications in Regards to the Subject of Information and Communication Technologies (MAAGTIC).

The structure in which the results are presented offers a bibliographic review which contains a brief test of the Models of Strategic Alignment between Business and IT, along with a MAAGTIC presentation; The methodology section, which describes the employed methods, techniques and information sources; and the results that, among its main findings, show the identification of variables that are already part of the analysis of the Strategic Alignment of the IT's evaluation administration. Finally, bibliographic references and annexes are provided.

\section{Bibliographic Review}

\subsection{TIC Business Alignment}

In order to achieve strategic alignment, organization oriented tools and models are required. Thus it is necessary to identify the organization's maturity level and, once those breaches have been identified, implement methodologies which allow reaching an optimal alignment level. Henderson \& Venkatraman (9) proposed the Strategic Alignment Model (SAM), which has been taken as a point of reference in various studies and is divided in four points of analysis:

- Business strategy

- Business structure

- IT strategy

- IT structure

The cross relations between these domains characterize different types of integration and alignment that can be addressed in the organization.

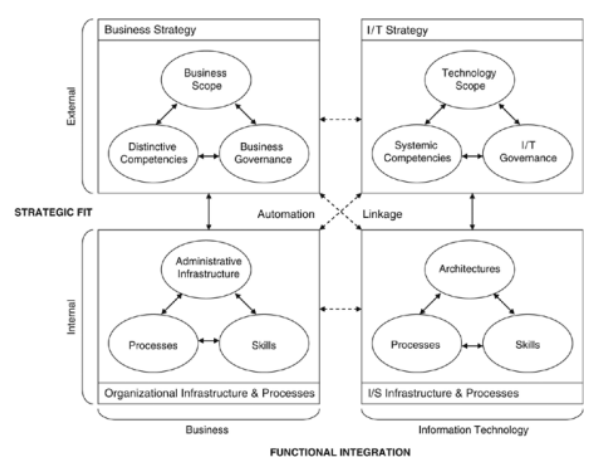

Fig. 1: Strategic Alignment Model (SAM). Source: (9)

On the other hand, one of the methodologies that allow the development of a measuring tool for the level of maturity of the Business and IT alignment within an organization is the Strategic Alignment Maturity Model (SAMM) (3-5, 10-13).

The Strategic Alignment Maturity Model incorporates an evaluation concept for the maturity of the organization in regards to its strategic alignment.

Diagnosing the alignment level of a company:

- Allows finding the maturity of the strategic decisions.

- Allows knowing how and where it is located, as well as how to improve it.

- Once that the level of maturity

- has been found, opportunities to improve the Business-IT relationship can be identified.

In order to measure the maturity level currently taking place in the alignment between the organization and IT, the SAMM Model proposes that the maturity level of the Business and IT alignment can be measured through 6 components, see table 1:

- Communications

- IT Value

- IT Governance

- Partnership

- Scope and Architecture

- Skills

Once measured, the score allows placing the organization in one of the five maturity levels, with the fifth being the optimal one. $(5,13)$

Level 1: Initial. These organizations usually have a poor level of communication between the Business and IT. There is also a poor understanding of the value or contributions they provide.

Level 2: Committed. Organizations in level two have begun to improve their Business-IT relationships.

Level 3: Focused. IT has been integrated throughout the organization. High and medium management levels understand the business and an understanding of IT begins to emerge on the business side.

Level 4: Improved and Managed. Organizations manage the processes they need for their strategic alignment. One of this level's main characteristics is that the Business-IT breach has been closed.

Level 5: Optimized. At this level organizations have optimized the strategic alignment between the business and the IT through rigorous business processes of integrated strategic business plans and the plans of IT. 
Table 1. SAMM and its areas, maturity levels, and attributes. Source: (5)

\begin{tabular}{l} 
Criteria \\
\hline Communications \\
Measures the effectiveness of the exchange of ideas, knowledge, and \\
information between IT and business organizations, enabling both to \\
clearly understand the company's strategies, plans, business and IT \\
environments, risks, priorities, and how to achieve them.
\end{tabular}

\section{Value}

Uses balanced measurements to demonstrate the contributions of information technology and the IT organization to the business in terms that both the business and IT understand and accept.
Level 1 Attribute

\begin{tabular}{|c|c|}
\hline 1 & Business/IT lack understanding \\
\hline 2 & Limited business/IT understanding \\
\hline 3 & $\begin{array}{l}\text { Good understanding; relaxed } \\
\text { communications emerging }\end{array}$ \\
\hline 4 & Bonding, unified \\
\hline 5 & Informal, pervasive \\
\hline 1 & Some technical measurements \\
\hline 2 & Measures functional cost efficiency \\
\hline 3 & $\begin{array}{l}\text { Measures some cost effectiveness; } \\
\text { Dashboard established. }\end{array}$ \\
\hline 4 & $\begin{array}{l}\text { Measures cost effectiveness; some } \\
\text { partner value; Dashboard managed }\end{array}$ \\
\hline 5 & $\begin{array}{l}\text { Measures extented to external } \\
\text { partners }\end{array}$ \\
\hline 1 & $\begin{array}{l}\text { No formal Process, cost center, } \\
\text { reactive priorities }\end{array}$ \\
\hline 2 & $\begin{array}{l}\text { Tactical at functional level, } \\
\text { occasionally responsive }\end{array}$ \\
\hline 3 & $\begin{array}{l}\text { Relevant Process across the } \\
\text { organization }\end{array}$ \\
\hline 4 & Managed across the organization \\
\hline 5 & $\begin{array}{l}\text { Integrated across the firm and } \\
\text { partners }\end{array}$ \\
\hline 1 & $\begin{array}{l}\text { Conflict; IT is a cost of doing } \\
\text { business }\end{array}$ \\
\hline 2 & $\begin{array}{l}\text { IT emerging as an asset; Process } \\
\text { enabler }\end{array}$ \\
\hline 3 & $\begin{array}{l}\text { IT is as an asset; Process driver; } \\
\text { conflict seen as creative }\end{array}$ \\
\hline 4 & IT enables/drives business strategy \\
\hline 5 & $\begin{array}{l}\text { IT-business adaptive and improvise } \\
\text { together }\end{array}$ \\
\hline 1 & Traditional (e.g., ESS,DSS) \\
\hline 2 & Transactional (e.g., ESS,DSS) \\
\hline 3 & Integrated across the organization \\
\hline 4 & Integrated with partners \\
\hline 5 & Evolve with partners \\
\hline 1 & $\begin{array}{l}\text { IT takes risks, little reward; } \\
\text { technical training only }\end{array}$ \\
\hline 2 & $\begin{array}{l}\text { Differs across functional } \\
\text { organizations }\end{array}$ \\
\hline 3 & $\begin{array}{l}\text { Emerging value Service provider; } \\
\text { Balanced technical and business } \\
\text { hiring }\end{array}$ \\
\hline 4 & Shared risks and rewards \\
\hline 5 & $\begin{array}{l}\text { Education/Careers/Rewards across } \\
\text { the organization }\end{array}$ \\
\hline
\end{tabular}

\section{Governance}

Defines who has the authority to make IT decisions and what processes IT and business managers use at strategic, tactical, and operational levels to set IT priorities to allocate IT resources.

\section{Partnership}

Gauges the relationship between a business and IT organization, including IT's role in defining the business's strategies, the degree of trust between the two organizations, and how each perceives the other's contribution.

\section{Scope \& Architecture}

Measures IT's provision of a flexible infrastructure, its evaluation and application of emerging technologies, its enabling or driving business process changes, and its delivery of valuable customized solutions to internal business units and external customers or partners.

\section{Skills}

Measures human resources practices, such as hiring, retention, training, performance feedback, encouraging innovation and career opportunities, and developing the skills of individuals. It also measures the organization's readiness for change, capability for learning, and ability to leverage new ideas.

\subsection{MAAGTIC}

The Administrative Manual of General Applications in Regards to the Subject of Information and
Communications Technologies (MAAGTIC) developed by the Mexican Government is an interesting proposal that integrates different reference frameworks and good IT practices such as: Information Technology Infrastructure Library (ITIL), Control Objectives for Information and 
related Technology (COBIT), Capability Maturity Model Integration (CMMI), ISO 27000.

The MAAGTIC contains the rules, actions, and processes necessary to define the processes regarding Information and Communication Technologies (TIC) and information security that should be undertaken in a mandatory manner by the Mexican Public Federal entities in order to regulate and homologize its management.

Its structure is divided in four "Management levels", each one containing "process groups". There is a total of 11 "process groups", each of which is integrated by 29 processes and, upon closer inspection, the manual as a whole describes a total of 160 sub processes that the IT Administration Units have to execute in order to achieve a strategic alignment between the Business and IT.

Under the context of this study, only Government level management is analyzed. Said level is composed by two groups of processes, IT Control and Direction (DR) and Information Security Control and Direction (DCSI), which are composed by the six processes mentioned ahead. The DR process group consists of 4 processes: IT Government Model Establishment (EMG), IT Strategic Planning (PE), Technological Direction Determination (DDT), and IT Evaluation Administration (AE), and the DCSI process Group consists of two processes; Information Security Administration (ASI) and Information Security Control and IT Security Incidents Response Team (OPEC).

\section{Methodology}

The data was collected by using a construct which in turn was based on the 6 processes regarding Government level Management, for which the MAAGTIC proposes a total of 38 sub processes with the goal of establishing an IT Government model within the Government level Management.

Both the construct and the data evaluation methods were adapted to the methodologies presented by Chen (14) and Sledgianowski (15) with the goal of obtaining the Government level Management sub processes offered by the MAAGTIC that would be the most relevant to our study. In order to apply this construct, it was necessary to create a web system which contained a list of critical factors and sub processes that integrate each one of them. The system provides a 5 point Lickert scale, with 1 being "In total disagreement" and 5 being "In total agreement", with the purpose of evaluating the importance of each factor.

For the completion of these surveys, a degree of relevance is given to the experts criteria, which has already proven useful when validating both the construct and its content or establishing the appropriate elements to consider in the conceptual framework of the study's objectives.
When selecting our experts, we took into consideration a certain criteria with the goal of making the selection as adequate as possible:

- On the business side, experts belong to Logistics, General Maintenance and Engineering \& Construction. On the IT side, they are experts in infrastructure, processes and Management.

- On the business side, professionals with over ten years of experience, business process owners, decision makers in the sub processes flow, and employees generating or modifying information for each input or product of the substantive processes and sub processes of the business line. On the IT side, professionals with an 18 year average experience both in the business and IT.

- Certified in ITIL v3, COBIT 4.1, 6 Sigma, Information Technology Tools, Microsoft Certified Solutions Developer (MCSD), Microsoft Certified Applications Developer (MSAD), Data Base Administrator (DBA), Oracle, Data Base Administrator (DBA), SqlServer.

Once the results of the expert based evaluation have been obtained, we proceed to make an analysis to determine those sub processes that, along with their critical factors, support integration with the alignment criteria proposed by Luftman in his SAM Model.

In order to partake in the previously mentioned selection of relevant processes, it is necessary to analyze the impact that a reduction of variables would make as a whole. For that reason, these studies are done via the use of IBM SPSS v20 software First, to evaluate the possibility of reducing the group of variables, a Kaiser-Meyer-Olkin (KMO) study is done, followed by a Bartlett Sphericity test with the goal of evaluating the possibility of a reduction.

After these tests, a (multiple) Correspondence analysis was done, which is a statistical technique used to analyze the dependence and independence relationships of a group of categorical variables based on the study data, which shows the appropriate weight and inertia for each variable, allowing us to identify those with the significance needed in order to be considered as a part of the study.

In order to do a correspondence analysis of the Government level Management, it is necessary to divide it into two parts, since it is formed by two groups of processes, IT Direction and Control (DR) and Information Security Direction and Control (DCSI), with the process taking place as follows in both groups; We first take the processes as a line and define their rank. The DR process group covers the first four processes (EMG, PE, DDT, AE) while the DCSI covers the last two (ASI, OPEC). In both cases we select as columns the sub processes that correspond to each group, and lastly we proceed to define 
the graphic and statistical models that will be shown in the results.

By making use of Decision trees, it is possible to get a better picture of the multiple variables, allowing us to know which ones posses a higher value within a specific group, enabling their identification, segmentation and discovery within the group.

Within the Decision tree making process, we select the processes as a dependent variable while defining the categories of processes as objectives. As for the independent variables, we selected the sub processes and their corresponding critical factors, and for influence variables we have the Lickert scale, which has had its criteria adjusted with the CHAID (Chi-squared Automatic Interaction Detector) option, the statistics of Chi-squared as a mean of plausibility, and lastly, we just select a method of growth deemed as appropriate for our study's decision tree.

With four possibilities of growing's algorithms for decision trees (CHAID, exhaustive CHAID, CRT, QUEST), we decided on the characteristic of our study and the data collected, Exhaustive CHAID, discarding CRT (Classification and Regression Trees) y QUEST(Quick, Unbiased, Efficient, Statistical Tree). (16)

The principal reason to choose this growing method, Exhaustive CHAID, to characterize the segments, was because of we were looking for the highest sensibility for the categorical variables of our sample (groups of processes, processes, sub processes and critical factors) in addition that the method for calculating the combinations of the categories of the predictors variables is more accurate. (17)

In order to validate the results obtained with the mentioned techniques and ensure that previous analysis have proven accurate, we applied a discriminant analysis, which is a technique used to classify the variables or cases in any of the groups established by the dependent variable. Unlike other analyzis (Cluster Analysis), in this, membership groups are already established and the purpose is to identify the variables that best discriminate, characterize and differentiate the groups.

The discriminant analysis was applied by selecting a grouping variable which in this case were the sub processes, setting the range covering all the sub processes contained within the Government level management established by the MAAGTIC, same which are formed by groups of Process Management and Control IT (DR) and Management and Control of Information Security (DCSI) as independent variables selected critical factors and as selection variables defined by the Government level management.
With all tests and analyzes performed on the MAAGTIC set of variables, we achieved the establishment of those sub processes that have a greater significance within MAAGTIC's Government level management, associating it logically with the government's alignment criteria proposed by Luftman's Strategic Alignment Model.

\section{Results}

Below are the different results obtained by various tests on the data, we must remember that this data was obtained from the evaluation construct of Government level management proposed by the MAAGTIC. Table 2 shows the results obtained in KMO and Bartlett sphericity tests, which supports the feasibility of reduction.

Table 2: Results of KMO and Bartlett Sphericity tests

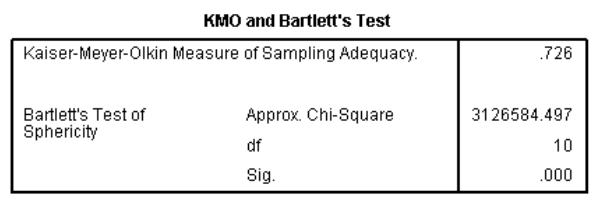

The results show that a KMO .726 level is obtained, which exceeds the 0.5 level recommended for the feasibility of the reduction, Bartlett's test of sphericity, which gives a significance equal to .000 , indicates that there is enough of a correlation between variables to proceed to the reduction because it proposes that values closest to zero are best suited to it.

Based on the information obtained in both tests, we can determine which set of variables can be reduced without affecting the object from the study variables.

Decision trees allow us to visualize in a graphical way the processes that are the most relevant, see Figure 2 and 3, to view them in a better way, the graphics are available in Appendix A.

Fig. 2: Decision tree, Group of processes DR

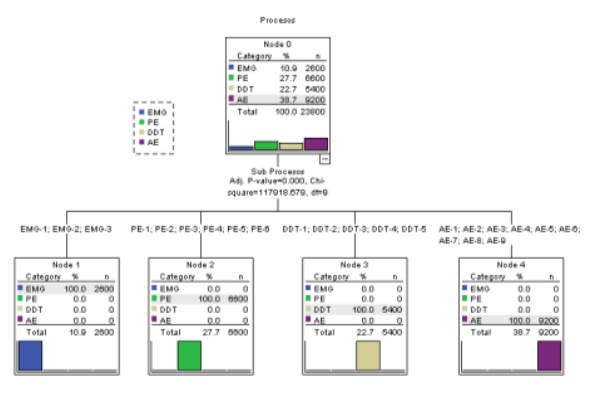


Fig. 3: Decision tree, Group of processes DCSI

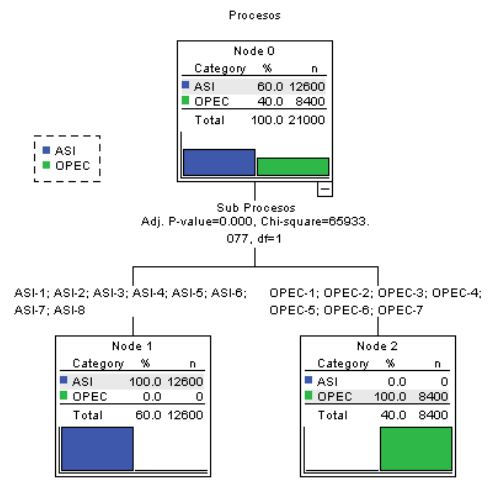

We can also observe, in Table 3 and 4, the mass (with more mass, the relative importance of the corresponding category is greater) and inertia (when is greater, more dependents will be the variables and more meaningful will have to identify who or what categories are involving more prominence in that group) (16), obtained for each of the sub processes (see Appendix B) contained within process groups IT Management and Control (DR) and Management and Control of Information Security (DCSI).

Table 3: Mass and Inertia of the sub processes contained within group of Process DR

\begin{tabular}{|c|c|c|}
\hline Sub Procesos & Mass & Inertia \\
\hline EMG-1 & .017 & .137 \\
\hline EMG-2 & .034 & .274 \\
\hline EMG-3 & .059 & .480 \\
\hline PE-1 & .042 & .109 \\
\hline PE-2 & .059 & .153 \\
\hline PE-3 & .067 & .175 \\
\hline PE-4 & .034 & .088 \\
\hline PE-5 & .042 & .109 \\
\hline PE-6 & .034 & .088 \\
\hline DDT-1 & .017 & .057 \\
\hline DDT-2 & .050 & .172 \\
\hline DDT-3 & .101 & .344 \\
\hline DDT- 4 & .017 & .057 \\
\hline DDT-5 & .042 & .143 \\
\hline AE-1 & .042 & .067 \\
\hline AE-2 & .067 & .107 \\
\hline AE-3 & .042 & .067 \\
\hline $\mathrm{AE}-4$ & .034 & .053 \\
\hline AE-5 & .042 & .067 \\
\hline AE-6 & .042 & .067 \\
\hline AE-7 & .025 & .040 \\
\hline AE-8 & .050 & .080 \\
\hline AE-9 & .042 & .067 \\
\hline Active Total & 1.000 & 3.000 \\
\hline
\end{tabular}

Table 4: Mass and Inertia of the sub processes contained within group of Process DCSI

\begin{tabular}{|l|r|r|}
\hline & & \\
Sub Procesos & Mass & \multicolumn{1}{c|}{ Inertia } \\
\hline ASI-1 & .029 & .019 \\
ASI-2 & .048 & .032 \\
ASI-3 & .086 & .057 \\
ASI-4 & .143 & .095 \\
ASI-5 & .048 & .032 \\
ASI-6 & .181 & .121 \\
ASI-7 & .019 & .013 \\
ASI-8 & .048 & .032 \\
OPEC-1 & .029 & .043 \\
OPEC-2 & .038 & .057 \\
OPEC-3 & .048 & .071 \\
OPEC-4 & .057 & .086 \\
OPEC-5 & .143 & .214 \\
OPEC-6 & .048 & .071 \\
OPEC-7 & .038 & .057 \\
Active Total & 1.000 & 1.000 \\
\hline
\end{tabular}

Also, is necessary to show the results obtained by the discriminant analysis, with them we can see the degree of dependence between variables. Both analysis are shown in Table 5 and 6.

Table 5: Discriminant analysis, Group of processes DR

Covariance Matrices $^{a}$

\begin{tabular}{|ll|r|}
\hline Sub Procesos & \multicolumn{1}{|c|}{$\begin{array}{c}\text { Factores } \\
\text { Criticos }\end{array}$} \\
\hline EMG-1 & Factores Criticos & .251 \\
\hline EMG-2 & Factores Criticos & 1.252 \\
\hline EMG-3 & Factores Criticos & 4.003 \\
\hline PE-1 & Factores Criticos & 2.002 \\
\hline PE-2 & Factores Criticos & 4.003 \\
\hline PE-3 & Factores Criticos & 5.253 \\
\hline PE-4 & Factores Criticos & 1.252 \\
\hline PE-5 & Factores Criticos & 2.002 \\
\hline PE-6 & Factores Criticos & 1.252 \\
\hline DDT-1 & Factores Criticos & .251 \\
\hline DDT-2 & Factores Criticos & 2.919 \\
\hline DDT-3 & Factores Criticos & 11.922 \\
\hline DDT-4 & Factores Criticos & .251 \\
\hline DDT-5 & Factores Criticos & 2.002 \\
\hline AE-1 & Factores Criticos & 2.002 \\
\hline AE-2 & Factores Criticos & 5.253 \\
\hline AE-3 & Factores Criticos & 2.002 \\
\hline AE-4 & Factores Criticos & 1.252 \\
\hline AE-5 & Factores Criticos & 2.002 \\
\hline AE-6 & Factores Criticos & 2.002 \\
\hline AE-7 & Factores Criticos & .668 \\
\hline AE-8 & Factores Criticos & 2.919 \\
\hline AE-9 & Factores Criticos & 2.002 \\
\hline Total & Factores Criticos & 1180.050 \\
\hline a. The total covariance matrix has \\
\hline
\end{tabular}


Table 6: Discriminant analysis, Group of processes DCSI Covariance Matrices $^{a}$

\begin{tabular}{|ll|r|}
\hline Sub Procesos & \multicolumn{1}{|c|}{$\begin{array}{c}\text { Factores } \\
\text { Criticos }\end{array}$} \\
\hline ASI-1 & Factores Criticos & .668 \\
\hline ASI-2 & Factores Criticos & 2.002 \\
\hline ASI-3 & Factores Criticos & 6.670 \\
\hline ASI-4 & Factores Criticos & 18.673 \\
\hline ASI-5 & Factores Criticos & 2.002 \\
\hline ASI-6 & Factores Criticos & 30.008 \\
\hline ASI-7 & Factores Criticos & .251 \\
\hline ASI-8 & Factores Criticos & 2.002 \\
\hline OPEC-1 & Factores Criticos & .668 \\
\hline OPEC-2 & Factores Criticos & 1.252 \\
\hline OPEC-3 & Factores Criticos & 2.002 \\
\hline OPEC-4 & Factores Criticos & 2.919 \\
\hline OPEC-5 & Factores Criticos & 18.673 \\
\hline OPEC-6 & Factores Criticos & 2.002 \\
\hline OPEC-7 & Factores Criticos & 1.252 \\
\hline Total & Factores Criticos & 918.710 \\
\hline \multicolumn{2}{|l|}{$\begin{array}{l}\text { a. The total covariance matrix has } 20999 \\
\text { degrees of freedom. }\end{array}$} \\
\hline
\end{tabular}

The discriminant analysis shows the Wilks' Lamba, see Table 7 , the value is .251 , this indicates that the variables can be discriminated.

Table 8: Integration of the Management Level Government-MAAGTIC with Government Alignment criterion-SAMM

\begin{tabular}{|c|l|l|}
\hline Criteria & \multicolumn{1}{|c|}{ Luftman } & \multicolumn{1}{c|}{ MAAGTIC } \\
\hline \multirow{5}{*}{ Government } & Business Strategic Plannig & Business Strategic Plannig \\
\cline { 2 - 3 } & IT Strategic Plannig & IT Strategic Plannig \\
\cline { 2 - 3 } & Organization Structure & Dropped \\
\cline { 2 - 3 } & Budgetary Control & Budgetary Control \\
\cline { 2 - 3 } & IT Investment Management & IT Investment Management \\
\cline { 2 - 3 } & Steering Committee(s) & Steering Committee(s) \\
\cline { 2 - 3 } & Prioritization Process & Prioritization Process \\
\hline
\end{tabular}

\section{Conclusions}

The results of the study identify, through the best sub processes present in the Government level management, those characteristics that make up the criteria of Government alignment that the organization needs to address.

The alignment criteria of the SAM model Government and the Government level management complement themselves in an effective way, since the first shows the characteristics of alignment but does not specify how to carry them out, and the later shows the activities needed to perform without defining its objective. Therefore a fusion of both allows to create an instrument that measures the alignment between the business and the IT and in turn gives the list of critical factors as well as their deliverables and/or activities to cover the gaps that prevent the alignment with the business from governance
Table 7: Wilks's Lambda, Government level management.

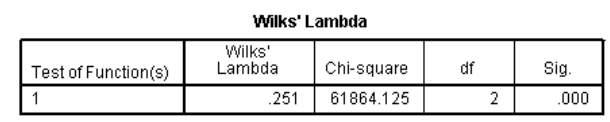

Based on the results shown after the application of much analysis, we obtain an integration of the sub processes with the higher value with the characteristics of the Government criteria of alignment proposed in the SAM Model shown in Table 8.
The future goal of this study is to cover all levels of management that make up the business and pairing logic with all the SAM alignment criteria, thus obtaining an instrument that enables the measurement of both the level of alignment between the business and the IT, and the necessary activities so that organizations comply with it.

\section{References}

[1] Symons C. IT Strategy Maps: A Tool For Strategic Alignment. Forrester Research, Nov. 2005;21.

[2] Burlton R. Delivering business strategy through process management. Handbook on Business Process Management 2: Springer; 2010. p. 5-37.

[3] Baets W. Aligning information systems with business strategy. The Journal of Strategic Information Systems. 1992;1(4):205-13.

[4] David N, Robert K. The Balanced ScorecardMeasures That Drive Performances. Harvard Business Review, Jarl, f'eb1992. 1992;70. 
[5] Luftman J, Kempaiah R. An update on businessIT alignment:“A line" has been drawn. MIS Quarterly Executive. 2007;6(3):165-77.

[6] OGC, ITGI. Alineando COBIT 4.1 ITIL V3 e ISO / IEC 27002 en beneficio del negocio. Un reporte para gestión del ITGI y OGC. Londres, Inglaterra: OGC; 2008.

[7] Siurdyban A. Understanding the IT/business partnership: A business process perspective. Inf Syst Front. 2012 2012/10/01:1-14. English.

[8] Lee M. Enterprise Architecture: Beyond Business and IT Alignment. In: Benghozi P-J, Krob D, Rowe F, editors. Digital Enterprise Design and Management 2013. Advances in Intelligent Systems and Computing. 205: Springer Berlin Heidelberg; 2013. p. 57-66.

[9] Henderson JC, Venkatraman N. Strategic alignment: leveraging information technology for transforming organizations. IBM systems journal. 1993;32(1):4-16.

[10] Kaplan RS, Norton D. The execution premium: Integrando la estrategia y las operaciones para lograr ventajas competitivas: Deusto; 2008.

[11] López Paz CR, Maciá Pérez F, Gilart Iglesias V. Modelo de consultoría genérico para alinear las Tecnologías de la Información con el Negocio en el sector de la fabricación industrial. 2009.
[12] vom Brocke J. Handbook on business process management 1: Springer; 2010.

[13] Ahuja S. Strategic Alignment Maturity Model (SAMM) in a Cascading Balanced Scorecard (BSC) Environment: Utilization and Challenges. In: Bajec M, Eder J, editors. Advanced Information Systems Engineering Workshops. Lecture Notes in Business Information Processing. 112: Springer Berlin Heidelberg; 2012. p. 567-79.

[14] Chen L. Business-IT alignment maturity of companies in China. Information \& management. 2010;47(1):9-16.

[15] Sledgianowski D. Strategic Alignment Maturity as a Predictor of Employee Awareness of Organizational Objectives. Strategic Management Review. 2009;3(1):116.

[16] Berlanga V, Rubio Hurtado MJ, Vilà Baños R. Cómo aplicar árboles de decisión en SPSS. REIRE

Revista d'Innovació i Recerca en Educació, 2013, vol 6, num 1, p 65-79. 2013.

[17] Fuentes MTM, González MVR. Utilización de modelos de predicción del uso de la tecnología como base para la segmentación: Una aplicación al sector sanitario: Editorial Dykinson, S.L.; 2006. 


\section{Appendix A. Decision trees}

Groups of processes DR

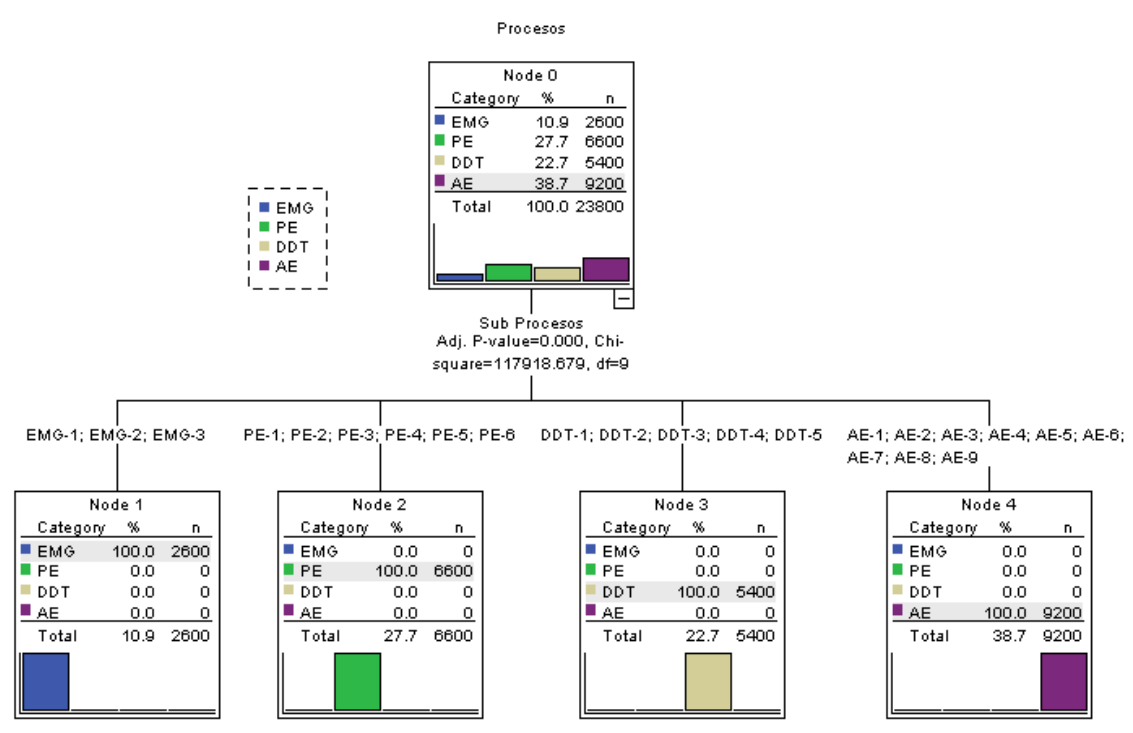

Groups of processes DCSI

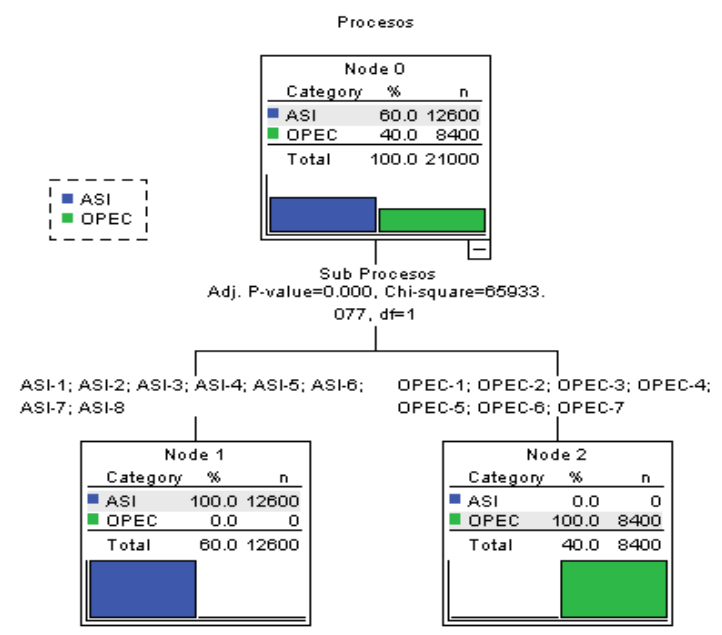


Appendix B. List of Sub processes of MAAGTIC, Management level Government

\begin{tabular}{|c|c|}
\hline Clave & Subproceso \\
\hline EMG-1 & $\begin{array}{l}\text { Establecer un modelo de gobierno de TI } \\
\text { (Establish an IT governance model) }\end{array}$ \\
\hline EMG-2 & $\begin{array}{l}\text { Establecer y mantener una adecuada organización de la Unidad } \\
\text { Administrativa de TI (UTI) } \\
\text { (Establish and maintain an adequate organization of the IT administrative } \\
\text { unit) }\end{array}$ \\
\hline EMG-3 & $\begin{array}{l}\text { Operar y mantener un Gobierno de TI } \\
\text { (Operate and maintain an IT governance) }\end{array}$ \\
\hline PE-1 & $\begin{array}{l}\text { Analizar el entorno en materia de TI } \\
\text { (Analyze the environment in terms of TI) }\end{array}$ \\
\hline PE-2 & $\begin{array}{l}\text { Establecer la misión, visión y estrategias de la Unidad Administrativa de TI } \\
\text { (UTI) (Establish the mission, vision and strategies of the IT administrative } \\
\text { unit) }\end{array}$ \\
\hline PE-3 & $\begin{array}{l}\text { Desarrollar el mapa estratégico y cuadro de mando integral de la Unidad } \\
\text { Administrativa de TI (UTI) } \\
\text { (Develop the strategy map and scorecard of the IT administrative unit) }\end{array}$ \\
\hline PE-4 & $\begin{array}{l}\text { Identificar las iniciativas y proyectos estratégicos de TI } \\
\text { (Identify strategic IT projects and initiatives) }\end{array}$ \\
\hline PE-5 & $\begin{array}{l}\text { Elaborar, validar, aprobar, comunicar y actualizar la planeación estratégica de } \\
\text { TI (PETI) (Develop, validate, approve, communicate and update the IT } \\
\text { strategic planning) }\end{array}$ \\
\hline PE-6 & $\begin{array}{l}\text { Dar seguimiento a la planeación estratégica de TI } \\
\text { (To follow up on the strategic planning of TI) }\end{array}$ \\
\hline DDT-1 & $\begin{array}{l}\text { Establecer el Grupo de trabajo de arquitectura tecnológica } \\
\text { (Establish the technological architecture working group) }\end{array}$ \\
\hline DDT-2 & $\begin{array}{l}\text { Determinar la visión de la tecnología } \\
\text { (Determine the vision of technology) }\end{array}$ \\
\hline DDT-3 & $\begin{array}{l}\text { Establecer y actualizar el Programa de tecnología } \\
\text { (Establish and update the technology program) }\end{array}$ \\
\hline DDT-4 & $\begin{array}{l}\text { Dar seguimiento a tendencias y a disposiciones normativas } \\
\text { (Track trends and regulatory provisions) }\end{array}$ \\
\hline DDT-5 & $\begin{array}{l}\text { Administrar los requerimientos tecnológicos } \\
\text { (Manage the technological requirements) }\end{array}$ \\
\hline
\end{tabular}




\begin{tabular}{|c|c|}
\hline AE-1 & $\begin{array}{l}\text { Establecer el sistema de evaluación de TI } \\
\text { (Establish the system of evaluation of IT) }\end{array}$ \\
\hline AE-2 & $\begin{array}{l}\text { Alinear los insumos y las métricas } \\
\text { (Align the inputs and metrics) }\end{array}$ \\
\hline AE-3 & $\begin{array}{l}\text { Especificar los mecanismos de recolección y almacenamiento } \\
\text { (Specify the collection and storage mechanisms) }\end{array}$ \\
\hline AE-4 & $\begin{array}{l}\text { Especificar los métodos de análisis } \\
\text { (Specify the analysis methods) }\end{array}$ \\
\hline AE-5 & $\begin{array}{l}\text { Establecer el Repositorio de métricas } \\
\text { (Set the repository from metrics) }\end{array}$ \\
\hline AE-6 & $\begin{array}{l}\text { Recolectar y revisar los datos insumo para las métricas } \\
\text { (Collect and review the data input for the metrics) }\end{array}$ \\
\hline AE-7 & $\begin{array}{l}\text { Elaborar Informes de medición y análisis } \\
\text { (Reporting of measurement and analysis) }\end{array}$ \\
\hline AE-8 & $\begin{array}{l}\text { Comunicar resultados a los grupos de trabajo y al Recurso humano en la } \\
\text { Unidad Administrativa de TI involucrado } \\
\text { (Communicating results to the working groups and the human resources } \\
\text { involved in the IT administrative unit) }\end{array}$ \\
\hline AE-9 & $\begin{array}{l}\text { Implementar acciones de mejora } \\
\text { (Implement actions to improve) }\end{array}$ \\
\hline ASI-1 & $\begin{array}{l}\text { Establecer un modelo de gobierno de seguridad de la información } \\
\text { (Establish an information security governance model) }\end{array}$ \\
\hline ASI-2 & $\begin{array}{l}\text { Operar y mantener el modelo de gobierno de seguridad de la información } \\
\text { (Operate and maintain the information security governance model) }\end{array}$ \\
\hline ASI-3 & $\begin{array}{l}\text { Diseño del Sistema de Gestión de Seguridad de la Información (SGSI) } \\
\text { (Design of the information security management system) }\end{array}$ \\
\hline ASI-4 & $\begin{array}{l}\text { Identificar las Infraestructuras críticas y los Activos clave } \\
\text { (Identify critical infrastructures and key assets) }\end{array}$ \\
\hline ASI-5 & $\begin{array}{l}\text { Establecer la Directriz rectora para la administración de riesgos } \\
\text { (Establish the governing guideline for risk management) }\end{array}$ \\
\hline ASI-6 & $\begin{array}{l}\text { Elaborar el Análisis de riesgos } \\
\text { (Develop risk analysis) }\end{array}$ \\
\hline ASI-7 & Integrar al Sistema de Gestión de Seguridad de la Información (SGSI) los \\
\hline
\end{tabular}




\begin{tabular}{|c|c|}
\hline & $\begin{array}{l}\text { controles mínimos de Seguridad de la información } \\
\text { (Integrate to the information security management system the minimum } \\
\text { information security controls) }\end{array}$ \\
\hline ASI-8 & $\begin{array}{l}\text { Mejorar el Sistema de Gestión de Seguridad de la Información (SGSI) } \\
\text { (Improve the management of security of information system) }\end{array}$ \\
\hline OPEC-1 & $\begin{array}{l}\text { Establecer el grupo de implantación de la seguridad } \\
\text { (Establish the Security deployment group) }\end{array}$ \\
\hline OPEC-2 & $\begin{array}{l}\text { Establecer los elementos de operación del Equipo de respuesta a incidentes de } \\
\text { seguridad en TI (ERISC) } \\
\text { (Establish the elements of operation of the security incident response team at } \\
\text { IT) }\end{array}$ \\
\hline OPEC-3 & $\begin{array}{l}\text { Operación del Equipo de respuesta a incidentes de seguridad en TI (ERISC) } \\
\text { en la atención de Incidentes } \\
\text { (The operation of incident response security in incidents attention) }\end{array}$ \\
\hline OPEC-4 & $\begin{array}{l}\text { Implantar los controles de mitigación de riesgos y los controles del Sistema de } \\
\text { Gestión de Seguridad de la Información (SGSI) } \\
\text { (Implement the system of management of the information security controls } \\
\text { and risk mitigation controls) }\end{array}$ \\
\hline OPEC-5 & $\begin{array}{l}\text { Implantar los controles del Sistema de Gestión de Seguridad de la } \\
\text { Información (SGSI) relacionados con los dominios tecnológicos de TI } \\
\text { (Implement the system of management of the information security controls } \\
\text { related to the technological domains of TI) }\end{array}$ \\
\hline OPEC-6 & $\begin{array}{l}\text { Revisar la operación del Sistema de Gestión de Seguridad de la Información } \\
\text { (SGSI) } \\
\text { (Check the operation of the system of management of the information } \\
\text { security) }\end{array}$ \\
\hline OPEC-7 & $\begin{array}{l}\text { Aplicar al Sistema de Gestión de Seguridad de la Información (SGSI) las } \\
\text { mejoras definidas por } \\
\text { el Grupo de trabajo estratégico de seguridad de la información } \\
\text { (Apply to the management of security of information system upgrades defined } \\
\text { by the strategic information security working group) }\end{array}$ \\
\hline
\end{tabular}

